Article

\title{
Entrepreneurial Intention of Engineering Students: The Role of Social Norms and Entrepreneurial Self-Efficacy
}

\author{
Grigorios Asimakopoulos*(D), Virginia Hernández and Javier Peña Miguel \\ Department of Mechanical Engineering; Institute of Entrepreneurship and Family Business, \\ Universidad Carlos III de Madrid, Avenida de la Universidad 30, 28911 Leganés, Spain \\ * Correspondence: gasimako@ing.uc3m.es
}

Received: 25 June 2019; Accepted: 6 August 2019; Published: 9 August 2019

check for updates

\begin{abstract}
This paper examines the impact of entrepreneurial education on intention to undertake entrepreneurial activity in the future. The study is based on a sample of 208 engineering students. Specifically, we explore the contingent effect of social norms on the relationship between entrepreneurial education and intention to undertake entrepreneurial activity, as well as the role of social norms on the association between entrepreneurial self-efficacy and entrepreneurial intention. We utilize a comprehensive questionnaire distributed among engineering students. Our findings indicate that entrepreneurial education is positively associated with the intention to undertake entrepreneurial activity, in addition to demonstrating a positive moderation effect role of social norms on the relationship between entrepreneurial self-efficacy and entrepreneurial intention. The study provides empirical support to devise new educational initiatives that can further support students and young entrepreneurs in their current or future entrepreneurial projects
\end{abstract}

Keywords: entrepreneurship; entrepreneurial intention; entrepreneurial education; social norms; entrepreneurial self-efficacy

\section{Introduction}

It has become well known during the last decades that entrepreneurship has gained much interest as a promoter of economic activity because of its great influence on the prosperity of a region or a country $[1,2]$. Entrepreneurs are considered as agents that accelerate economic development through the generation of ideas and their subsequent transformation into business projects [3]. The emergence of new companies is essential since they create employment, drive innovation, and increase efficiency in various economic sectors [1].

The degree of entrepreneurship of a region is linked to its economic prosperity and this is why policy makers are especially focused on fostering entrepreneurial activities, particularly among young people [4]. In this regard, entrepreneurial education has emerged as an important tool for that objective [5,6]. However, education currently offered in most countries does not promote, as it should, entrepreneurship or endow students with the much-needed "soft skills" such as leadership, responsibility, communication skills, or proactivity. The premise for encouraging entrepreneurship education is that it "can contribute to the development of students' entrepreneurial attitudes, abilities and skills, and hence enhance their intentions to launch new ventures" [7]. Consequently, the education system should be more involved in the teaching of entrepreneurship, transmitting to teachers and students the importance for society of identifying, defining, and stimulating, in all people, the qualities associated with the entrepreneurial attitude such as creativity, assumption of risks, ambition, audacity, perseverance, decision, confidence, determination, proactivity, efficiency, empathy, critical, and persuasive capacity [1]. 
According to studies on human psychology, intention has turned out to be the best predictor of planned and actual behavior. That is, knowing the intentions of people is the best way to predict their actual behavior, especially when it is difficult to observe them. Entrepreneurship is a typical example of this planned behavior [8]. If fact, having entrepreneurial intent-the self-acknowledged conviction by a person to set up a new business now or in the future-is a necessary condition for becoming an entrepreneur [9]. The theory of planned behavior (TPB) explains that intention is determined by attitudes, subjective or social norms, and perceived behavioral control [10]. Nevertheless, one of the critics for the TPB is that background factors, such as education or influencing beliefs, are expected to affect intentions, but they are not specified in this theory [11]. Then, recent literature has highlighted the role of entrepreneurial education programs, considering that entrepreneurial intention can be increased with improvement in skills, knowledge, and attitudes provided by these programs [2,12].

Regarding the effect of entrepreneurial education, evidence shows that there is a notable increase in entrepreneurship programs in schools and universities around the world [13,14]. From the contributions at the beginning of the 1990s to the present, the development of this type of studies has grown exponentially [15]. However, the results found in the literature regarding the effect of entrepreneurial education and entrepreneurial intention has been contradictory. Some of them find a negative relationship [16] whereas others find a positive effect $[17,18]$. Therefore, more studies are needed to be able to study all the uncertainties and factors that exist about the influence of entrepreneurship programs on the attitudes and intentions of people to entrepreneurial intention activity.

Additionally, regarding the own perception about becoming an entrepreneur abilities, also defined in the literature as entrepreneurial self-efficacy $[7,19]$, we also found some contradictory results in the literature. Despite that some scholars find that there is a positive relationship $[6,18,20]$, others find that the relationship is weaker, even non-existent, or only relevant when other factors are included $[7,21]$. In this sense, there is a call for more studies that could include moderation effects and shed light into these inconsistencies [21,22]. Precisely, we add to that purpose, and this is why we include the moderating effect of social norms in the model. Social norms include those factors related to the perceived support or pressure from the environment to create a business [23]. Previous research has explored the direct relationship between the perception of what some referents, such as close friends, family, etc., think about the entrepreneurial actions and the desire to start a business $[18,24]$. We go beyond this issue and explore moderation effects of social norms [19]. Overall, our objective is to investigate the interaction between entrepreneurial education, entrepreneurial self-efficacy, and social norms about entrepreneurial intention. Accordingly, the study explores the following research questions:

1. What is the relationship between entrepreneurial education and entrepreneurial intention?

2. What is the role of social norms on the relationship between entrepreneurial education and entrepreneurial intention?

3. What is the role of social norms on the relationship between entrepreneurial self-efficacy and entrepreneurial intention?

This study contributes to the literature in several ways. On the one hand, we follow some scholars that posit the necessity of including background factors, such as entrepreneurial education, in order to enrich and expand intention models [11]. Moreover, we sum to the line pointed by recent scholars that remark the necessity of exploring the moderation effects in the relations between entrepreneurial education and intention [25], and between self-efficacy and intention [19,21]. Specifically, we highlight the role of perceived social norms as factors that alter or modify those relationships [26]. With it, we extend the planned behavioral theory by examining moderation effects that could explain with more detail how entrepreneurial intention can be increased.

This study is based on a sample of engineering students with high requirements for social and economic development. It should be noted that university engineering careers offer a highly useful technological vision for potential entrepreneurs when creating technology-based companies [8]. 
With all this, engineers would have great opportunities to take over entrepreneurial projects if, in addition to the knowledge that an engineering career brings them, they learn to plan, to encourage their creativity and innovation, to deal with uncertainties, and to evaluate business opportunities [27]. Thus, engineering is at the service of technological innovation and a part of the evolution of society depends on it. Moreover, there is a call in the literature for examining the way science and engineering students can increase their entrepreneurial intentions [28]. For these reasons, we think it is relevant the analysis of entrepreneurial intention of engineering students, because engineering is one of the main vehicles for the activation of entrepreneurship today's society. A strategy based on the development of these competences will enable future graduates to do so with their knowledge, skills, and attitudes that business creation processes require [15].

This study is relevant in a context in which it aims to enhance skills such as creativity and initiative, as well as promoting a culture in the society of sustainable wealth creation and lifelong learning to achieve a better world [1]. To carry out this study, a questionnaire was distributed to the engineering students of the Carlos III University of Madrid (UC3M). The paper is structured as follows: First, we review the literature on the topic and formulate and describe our study hypotheses. After that, the data obtained, and the methodology used to analyze these data, are explained. The next section presents and explain the study results. Lastly, conclusions are drawn for entrepreneurial education and entrepreneurial intention.

\section{Theoretical Background and Hypotheses}

The literature has examined several factors in order to explain the decision to become and entrepreneur: From those studies focused on personality variables to those that try to explain the phenomenon based on demographic variables [29-31]. More recently, the literature has assumed that the average entrepreneur does not exist, and little by little has moved to "intention" models that explain how the entrepreneurial intention is based on a voluntary and conscious decision, in which the perceived attitudes together with the perceived social factors are crucial [26,32].

In order to explain entrepreneurial intention, different approaches have been considered in the literature. Among the most common we find the theory of planned behavior (TPB) [10] and Shapero's model of the entrepreneurial event (SEE) [33]. Both are complementary by focusing on the individual willingness, but at the same time present differences. One of the main differences is that whereas TPB takes into account, together with the attitude towards the behavior and the perceived behavioral control, the effect of social influences or social norms, in the SEE perspective, these social norms are integrated in the perceived desirability of starting a business [34]. However, these theories have been criticized for not comprehensively investigating the contribution of exogenous factors such as the effect of entrepreneurial education. In fact, the effect of entrepreneurship education on entrepreneurial intention needs further research [35].

The literature review about entrepreneurship and, more specifically, about the entrepreneurial intention of university students, has allowed us to identify the most influential factors, and the extent of students' pretension of creating companies in a future. Thus, considering the existing literature, it seems that the entrepreneurial intention is affected by various endogenous factors [36] such as attitudes and perceptions, but also by exogenous factors such as the education that the person has received [8,35,37]. Moreover, the perceived context—such as social norms-may directly affect entrepreneurial intention [18], however some scholars observe that it is the weakest element affecting entrepreneurial intention [10,38], or some even find a non-significant direct effect [24,26,32]. This is the reason that the literature has also considered the analysis of the indirect effect of social norms by moderating different relationships [19]. Thus, we focus on the examination of different relationships between entrepreneurial education intention, social norms, and entrepreneurial self-efficacy to provide a comprehensive model about these issues. 


\subsection{Entrepreneurial Education}

Education has been considered a driver of entrepreneurship [35,39]. Several benefits from entrepreneurial education have been found in the literature. In fact, [25] shows that the relationship between entrepreneurial education and entrepreneurial intention is stronger than the relation between general business education and entrepreneurial intention. Many authors talk about the close relationship between entrepreneurial education and the intention to undertake entrepreneurial activity, due to the increase in the perceived ability, in the students' knowledge, and in the confidence, the resources, and inspiration that, in turn, will cause them greater desire to create a company $[8,40]$. However, several of the results of previous studies are inconsistent [14,16,41].

On the one hand, the conclusion reached by [17] in their study was that after an educational entrepreneurship program, the capacity and desire to start a business increased. Similarly, [8] show that a greater intention is obtained to create a business of their own after that training. On the other hand, other research finds different results, such as the study by [14], arguing that the differences between entrepreneurial intention before and after having gone through an entrepreneurship course were not significant. However, the fact that these courses were mandatory may explain these results. In addition, in reference to the inconsistent results, there are many studies on the impact of entrepreneurial education that have been carried out with a single test after the program [14].

Generally, in this type of literature, there is no distinction between the programs that are done inside or outside the university, nor if they are optional or mandatory; nevertheless, these aspects are extremely important. Another very common limiting factor of this type of studies is the small sample size. Therefore, the results cannot be extrapolated indistinctly for other groups. Moreover, other factors can be considered. For example, the fact of analyzing engineering students. These students have a higher risk-taking propensity compared to others [29,35]; therefore, we argue that those with an entrepreneurial education can assume the risks of being entrepreneurs because they are more prepared to recognize more opportunities [32,35]. In short, we believe that entrepreneurial education provides students—especially engineering students—with skills to better recognize business opportunities, identify problems, and generate ideas [14,42]. Therefore, we also argue that people who follow an entrepreneurial education program acquire greater capacity and desire to create their own business. We propose the following hypothesis:

H1. There is a positive impact of entrepreneurial education on entrepreneurial intention.

\subsection{Social Norms and Entrepreneurial Education}

Social norms are understood as the perceived social pressure exerted by the environment to perform or not perform a certain behavior; in this case, to start a business $[10,32,43]$. Social norms are linked to our perceptions of what important people in our lives would think about our entrepreneurial project [40]. In other words, whether the people we consider important would approve, or not, our decision to create a company [44]. However, social norms do not only refer to important people around us such as family and friends, but also influence of the environment where we educate ourselves. When students perceive that their environment, including the university with its environment and its policies, supports them in entrepreneurship, they may be more inclined to start a business [6].

On the one hand, according to [45], cultural values and the level of business activity of a locality affect the decision to undertake. In this context, [46] explain that the support and promotion of entrepreneurship by the university manages to increase the entrepreneurial intention of the students of the same. In turn, [47] highlight, apart from the approval of friends and family, the presence of an entrepreneur among them as key to this positive effect on the individual.

In part of the literature on entrepreneurship, we find that social norms are positively related to entrepreneurial behavior [8]. Similarly, [3] argue that the sentimental and monetary support of the family positively influences the entrepreneurial intention. Beyond family and friends, other social supports can be important, such as partners and even other people from the immediate environment. 
However, there are numerous studies that do not find a significant positive relationship between social norms and entrepreneurial intention [18]. Social norms are frequently one of the weakest elements in relation to the influence on the intention to undertake $[10,38]$. The possible explanation of these results is that, depending on which studies, social norms may directly affect entrepreneurial intention, or do so indirectly $[38,48]$. Likewise, students who are trained in an entrepreneurship course may feel that they can extract more benefit from this education if they have the support of their environment. As a result of these arguments, we argue that people who attend an entrepreneurial education program are more likely to have the intention of undertaking when they perceive an environment that supports them. Consequently, we formulate the following hypothesis:

H2. Social norms have a positive moderating effect on the relationship between entrepreneurial education and entrepreneurial intention.

\subsection{Social Norms and Entrepreneurial Self-Efficacy}

The entrepreneurial [perceived] self-efficacy refers to the difficulty or easiness perceived by oneself to perform a certain action; in this context, of being an entrepreneur. In other words, it is the belief of an individual in his personal capacity to carry out an activity, in this case, to create a company [32,40]. In addition, people with high self-efficacy for a task work harder and are more likely to pursue and then persist in that task than those with low self-efficacy [49,50].

Scientific evidence shows that entrepreneurial self-efficacy not only has a positive impact, but is one of the most important factors in entrepreneurial intention regardless of the region [32]. For [40], it is the most relevant factor for the creation of new companies. Therefore, it is the factor that must be promoted, and some of the reforms in education to promote entrepreneurship in young people should be aimed at increasing this perceived self-efficacy. Of course, promoting self-efficacy is not only teaching entrepreneurial skills. They should also show credible models of behavior and give psychological and emotional support.

However, there is contradictory reasoning in the moderation effect that social norms may have on the entrepreneurial self-efficacy and intention relation. Recent research points out that social norms exert a negative moderation effect on the relationship between entrepreneurial self-efficacy and intention, because social norms may be perceived as pressure factors [19]. On the contrary, according to [32], the presence of mentors or role models could be a decisive element in the level of individual entrepreneurial self-efficacy. We agree with the latter view because, in many cases, the perception of ability is more determinant than the real skills one must perform a certain behavior [51]. That is why we believe that the environment of a person can grow their perception of ability and, consequently, also their intention to undertake. Thus, we argue that the effect of entrepreneurial self-efficacy on the intention to undertake can be increased if there is a favorable environment for entrepreneurship. This leads us to formulate the following hypothesis:

H3. Social norms have a positive moderating effect on the relationship between entrepreneurial self-efficacy and entrepreneurial intention.

Our proposed model to explore these relationships are presented in Figure 1.

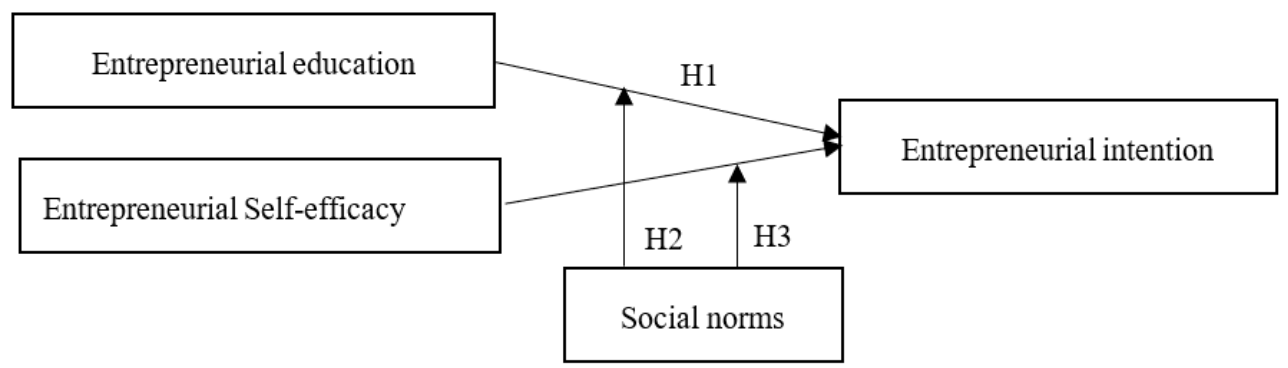

Figure 1. The conceptual model. 


\section{Methodology}

\subsection{Data Analysis and Descriptive Statistics}

In order to analyze the main factors influencing entrepreneurial intention and the level of influence, we created a questionnaire (see Appendix A), and we distributed it among engineering students at the Carlos III University of Madrid in Spain. The final sample consists of 208 completed surveys. All the descriptive statistics of each of the questions included in the paper is in Appendix B.

These responses to the questionnaire show that the average age of the respondents is between 20 and 22 years old. Further, $67.8 \%$ are men and the rest are women. The total monthly average income of the households of the people surveyed is between 2000 and 4000 euros. In addition, up to 110 people have had some type of work experience. On the other hand, $13.9 \%$ have been self-employed and 13\% have some family business where they plan to work. To measure entrepreneurial self-efficacy, five personal skills have been used, taking values between 1 (none) and 7 (very much). We have obtained considerably high scores (an average of 5) in the answers.

Of the 208 people, a total of 45 have completed an entrepreneurial education program. For this smaller group, we have studied the impact that the course has had on several aspects (knowledge about entrepreneurship, improvement of the image of entrepreneurs, and development of skills to undertake), obtaining an average result of around 4.5 points out of 7 .

On the other hand, on a scale of 1 (totally disagree) to 7 (totally agree), of the 208 participants, a very high average value has been obtained in terms of perceived barriers, 4.8 points specifically. This is something that is worrying and that can give us a clue to know where to direct policies to reduce the perception of barriers towards entrepreneurship. On the other hand, the support perceived by the students to learn is not very high, with an average value of 3.9 points out of seven. However, students' environment is favorable for entrepreneurship, since they feel support from family and friends is important with an average of more than 5 . Finally, it should be noted that the entrepreneurial intention of the students surveyed is not very high but depending on whether they have followed an entrepreneurship course, entrepreneurship intention differs significantly. This difference is shown in Figure 2. Likewise, we can also see a very small increase in the perceived levels of entrepreneurial self-efficacy and social norms.

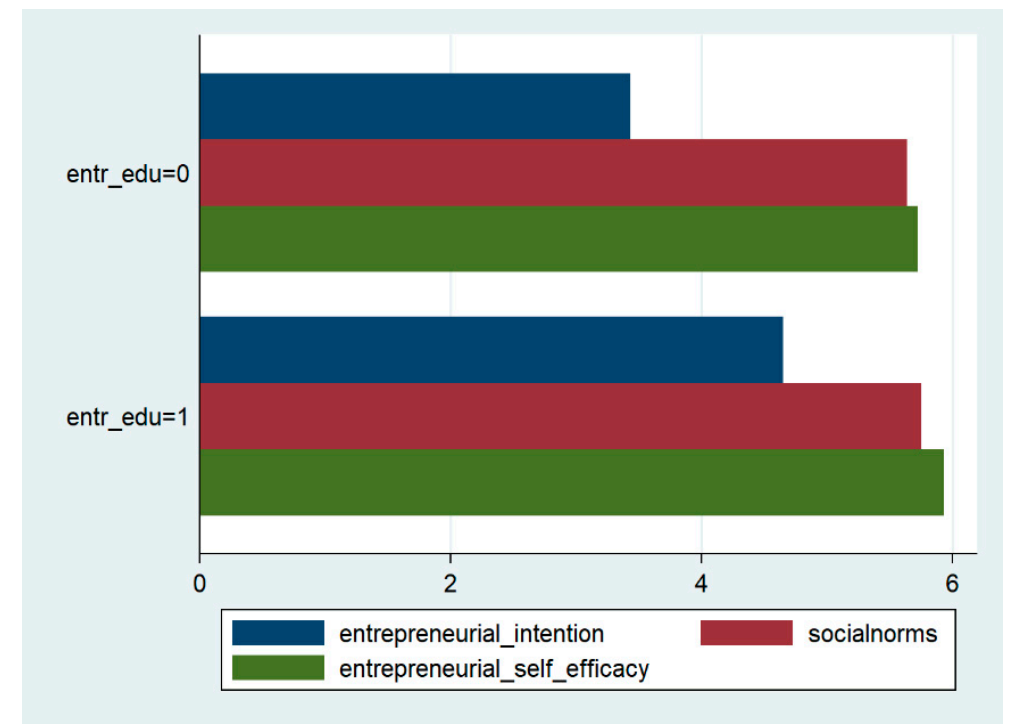

Figure 2. Entrepreneurial intention, self-efficacy, and social norms of students according to whether or not they have completed an entrepreneurial education program. 


\subsection{Model and Estimation}

The questionnaire carried out and distributed was based on previous studies related to entrepreneurial intention [8,36,52]. Thus, after having obtained the data from the questionnaire, the next step is to study the veracity of the hypotheses formulated from statistical techniques. For this, we have used factor analysis to construct our independent basic variables (or factors). That is, each question of the questionnaire was a variable and, these variables are grouped to form a total of seven factors (see Tables 1 and 2). In order to perform this analysis, we used a polychoric correlation matrix, since the standard methods of factorial analysis assume that the variables are continuous and follow a normal multivariate distribution [53].

Table 1. Factors obtained from the variables of the questionnaire questions.

\begin{tabular}{|c|c|c|c|c|c|}
\hline Factors & V1 & V2 & V3 & V4 & V5 \\
\hline ESE & Creativity & Problem solving skills & Leadership & Communication skills & Networking skills \\
\hline PERCBARR & Banks & Laws & Ideas & & \\
\hline PERCSUPP & University environment & Access to aid & Entrepreneur view & & \\
\hline REASSELFEMPL & Security & Interesting & Autonomy & Authority & \\
\hline $\mathrm{SN}$ & Family & Friends & Colleagues & Close circle & \\
\hline EI & At some point & EI 5 years & EI effort & & \\
\hline
\end{tabular}

Next, a table with the average values, standard deviation, minimum value, and maximum value of each factor is shown.

Table 2. Values obtained from the factors.

\begin{tabular}{llllll}
\hline Variable & Sample & Average & SD & Min & Max \\
\hline ESE & 208 & 5.769031 & 1.127717 & 2.012717 & 8.087558 \\
PERCBARR & 208 & 6.608376 & 3.026448 & -1.68127 & 14.98632 \\
PERCSUPP & 208 & 3.711329 & 0.98583 & 0.964373 & 5.786237 \\
REASSELFEMPL & 208 & 6.246605 & 0.919353 & 2.081982 & 7.646017 \\
SN & 208 & 5.665418 & 1.143488 & 2.458648 & 7.279726 \\
EDE & 208 & 0.2163462 & 0.4127463 & 0 & 1 \\
EI & 208 & 3.696529 & 1.672255 & 1.022173 & 7.15521 \\
\hline
\end{tabular}

In the first step, the polychoric correlations of each factor are derived by taking the estimate (of maximum probability) of the correlation of these variables assuming an underlying normal variation for each of them. In the second step, we used factor analysis based on the obtained correlation matrix and we used the orthogonal varimax rotation method to increase the interpretability of the resulting factor. OLS regression with robust standard errors has been used to estimate the models and test our hypotheses. Our dependent variable is entrepreneurial intention (EI). Our independent variables (or factors) are entrepreneurial education (EDE), social norms (SN), entrepreneurial self-efficacy (ESE), reasons to undertake (REASSELFEMPL), perceived support (PERCSUPP), perceived barriers (PERCBARR), age (AGE), gender (GENDER), income (INCOME), work experience (WORKEXP), self-employed (SELFEMPLOYED), and family business (FAMIBUSSINESS).

In addition, we have verified that we do not have problems of multicollinearity, as observed in Table 3 below. 
Table 3. Pearson correlation coefficients.

\begin{tabular}{|c|c|c|c|c|c|c|c|c|c|c|c|c|}
\hline & 1 & 2 & 3 & 4 & 5 & 6 & 7 & 8 & 9 & 10 & 11 & 12 \\
\hline \multicolumn{13}{|l|}{ 1. EI } \\
\hline 2. EDE & 0.3003 & & & & & & & & & & & \\
\hline 3. SN & 0.2227 & 0.0407 & & & & & & & & & & \\
\hline 4. ESE & 0.2843 & 0.0779 & 0.1266 & & & & & & & & & \\
\hline 5. REASSELFEMPL & 0.3473 & 0.0171 & 0.1682 & 0.3751 & & & & & & & & \\
\hline 6. PERCSUPP & -0.1308 & -0.1183 & 0.0119 & -0.0546 & -0.0422 & & & & & & & \\
\hline 7. PERCBARR & -0.1027 & -0.0318 & 0.0033 & -0.0112 & -0.0606 & 0.0003 & & & & & & \\
\hline 8. AGE & 0.0972 & 0.0955 & 0.1114 & 0.0316 & -0.0208 & -0.231 & -0.0257 & & & & & \\
\hline 9. GENDER & -0.0276 & -0.1126 & 0.0413 & 0.0208 & -0.1338 & 0.0632 & -0.0493 & -0.0309 & & & & \\
\hline 10. INCOME & 0.1356 & 0.0503 & 0.0527 & 0.1558 & 0.1182 & -0.0268 & -0.0641 & 0.0599 & 0.0943 & & & \\
\hline 11. WORKEXP & 0.1004 & 0.0047 & 0.0566 & 0.2633 & 0.0731 & -0.147 & 0.0342 & 0.266 & -0.0323 & 0.1342 & & \\
\hline 12. SELFEMPL & 0.0548 & 0.0245 & 0.0224 & 0.1067 & 0.1377 & -0.0324 & -0.0887 & 0.0814 & 0.0101 & 0.1813 & 0.2409 & \\
\hline 13. FAMIBUS & 0.1032 & 0.075 & -0.0347 & 0.1174 & 0.0578 & -0.083 & 0.0601 & 0.0559 & -0.0093 & 0.0589 & -0.0366 & 0.0923 \\
\hline
\end{tabular}




\section{Results}

The econometric results appear in Table 4. Model 2 of the table examines hypothesis 1 . As can be seen, there is a positive and significant effect of EDE on EI; thus, confirming our first hypothesis. To address our second hypothesis, we analyze the results in model 3 , where a positive and significant moderating effect is found between SN and EDE. For further study, we have examined the results by applying a simple slope analysis and as shown in Figure 3 it appears that, for high levels of SN (6.5), there is a positive and significant moderating effect on the relationship between EDE and EI, leading us to reject our second hypothesis since it is only checked for very high SN values. Finally, model 4 examines the moderating effect of SN on the relationship between ESE and EI. A positive and significant moderating effect of SN between ESE and EI can be seen in model 4. We, again, perform simple slope analysis to see at what ESE levels SN has a moderator role. Figure 4 shows that for high ESE values, SN has a statistically significant moderating effect between the relationship between ESE and EI, partially confirming our third hypothesis. The summary of the evaluation of the hypotheses is shown in the following table:

Table 4. Econometric results.

\begin{tabular}{|c|c|c|c|c|}
\hline & Model 1 & Model 2 & Model 3 & Model 4 \\
\hline REASSELFEMPL & $\begin{array}{c}0.599 * * * \\
(0.129)\end{array}$ & $\begin{array}{c}0.477^{* * *} \\
(0.127)\end{array}$ & $\begin{array}{c}0.977^{* *} \\
(0.407)\end{array}$ & $\begin{array}{c}0.492 * * * \\
(0.13)\end{array}$ \\
\hline PERCSUPP & $\begin{array}{c}-0.15 \\
(0.1)\end{array}$ & $\begin{array}{c}-0.118 \\
(0.0937)\end{array}$ & $\begin{array}{c}0.361 \\
(0.297)\end{array}$ & $\begin{array}{c}-0.117 \\
(0.0904)\end{array}$ \\
\hline PERCBARR & $\begin{array}{l}-0.0472 \\
(0.0377)\end{array}$ & $\begin{array}{l}-0.0442 \\
(0.0354)\end{array}$ & $\begin{array}{c}-0.191 \text { ** } \\
(0.0916)\end{array}$ & $\begin{array}{c}-0.0364 \\
(0.035)\end{array}$ \\
\hline AGE & $\begin{array}{c}0.173 \\
(0.204)\end{array}$ & $\begin{array}{l}0.0803 \\
(0.198)\end{array}$ & $\begin{array}{c}0.146 \\
(0.595)\end{array}$ & $\begin{array}{l}0.0612 \\
(0.194)\end{array}$ \\
\hline GENDER & $\begin{array}{l}0.0539 \\
(0.235)\end{array}$ & $\begin{array}{l}0.0953 \\
(0.219)\end{array}$ & $\begin{array}{l}-0.635 \\
(0.591)\end{array}$ & $\begin{array}{c}0.14 \\
(0.218)\end{array}$ \\
\hline INCOME & $\begin{array}{c}0.127 \\
(0.108)\end{array}$ & $\begin{array}{l}0.0845 \\
(0.098)\end{array}$ & $\begin{array}{c}-0.204 \\
(0.22)\end{array}$ & $\begin{array}{c}0.0815 \\
(0.0936)\end{array}$ \\
\hline WORKEXP & $\begin{array}{c}0.174 \\
(0.233)\end{array}$ & $\begin{array}{l}0.0984 \\
(0.235)\end{array}$ & $\begin{array}{c}0.196 \\
(0.584)\end{array}$ & $\begin{array}{l}0.0668 \\
(0.234)\end{array}$ \\
\hline SELFEMPL & $\begin{array}{r}-0.195 \\
(0.341)\end{array}$ & $\begin{array}{l}-0.183 \\
(0.285)\end{array}$ & $\begin{array}{c}2.088^{* *} \\
(0.935)\end{array}$ & $\begin{array}{l}-0.115 \\
(0.296)\end{array}$ \\
\hline FAMIBUS & $\begin{array}{c}0.395 \\
(0.288)\end{array}$ & $\begin{array}{c}0.289 \\
(0.252)\end{array}$ & $\begin{array}{c}-0.0366 \\
(0.674)\end{array}$ & $\begin{array}{c}0.275 \\
(0.247)\end{array}$ \\
\hline EDE & & $\begin{array}{c}1.068^{* * *} \\
(0.271)\end{array}$ & & $\begin{array}{c}1.045^{* * *} \\
(0.265)\end{array}$ \\
\hline SOCN & & $\begin{array}{c}0.216^{* *} \\
(0.1)\end{array}$ & $\begin{array}{c}-1.408 \text { * } \\
(0.744)\end{array}$ & $\begin{array}{c}-0.763^{* *} \\
(0.38)\end{array}$ \\
\hline ESE & & $\begin{array}{c}0.181 * \\
(0.0989)\end{array}$ & $\begin{array}{c}0.129 \\
(0.329)\end{array}$ & $\begin{array}{c}-0.778^{* *} \\
(0.338)\end{array}$ \\
\hline $\mathrm{SOCN} * \mathrm{ESE}$ & & & & $\begin{array}{l}0.170 * * * \\
(0.0601)\end{array}$ \\
\hline $\mathrm{EDE}=1 \mathrm{FACTOR}$ & & & $\begin{array}{l}-1.575 \\
(0.999)\end{array}$ & \\
\hline $\mathrm{EDE}=1 \mathrm{FACTOR} * \mathrm{SOCN}$ & & & $\begin{array}{l}0.289 * \\
(0.156)\end{array}$ & \\
\hline Constant & $\begin{array}{c}-0.0112 \\
(1.191)\end{array}$ & $\begin{array}{l}-1.624 \\
(1.188)\end{array}$ & $\begin{array}{c}6.251 \\
(4.844)\end{array}$ & $\begin{array}{c}3.707 \\
(2.3)\end{array}$ \\
\hline Observations & 208 & 208 & 45 & 208 \\
\hline r2 & 0.162 & 0.271 & 0.432 & 0.294 \\
\hline$F$-test & $3.92 * * *$ & $6.31^{* * *}$ & $3.43^{* * *}$ & $7.09 * * *$ \\
\hline
\end{tabular}




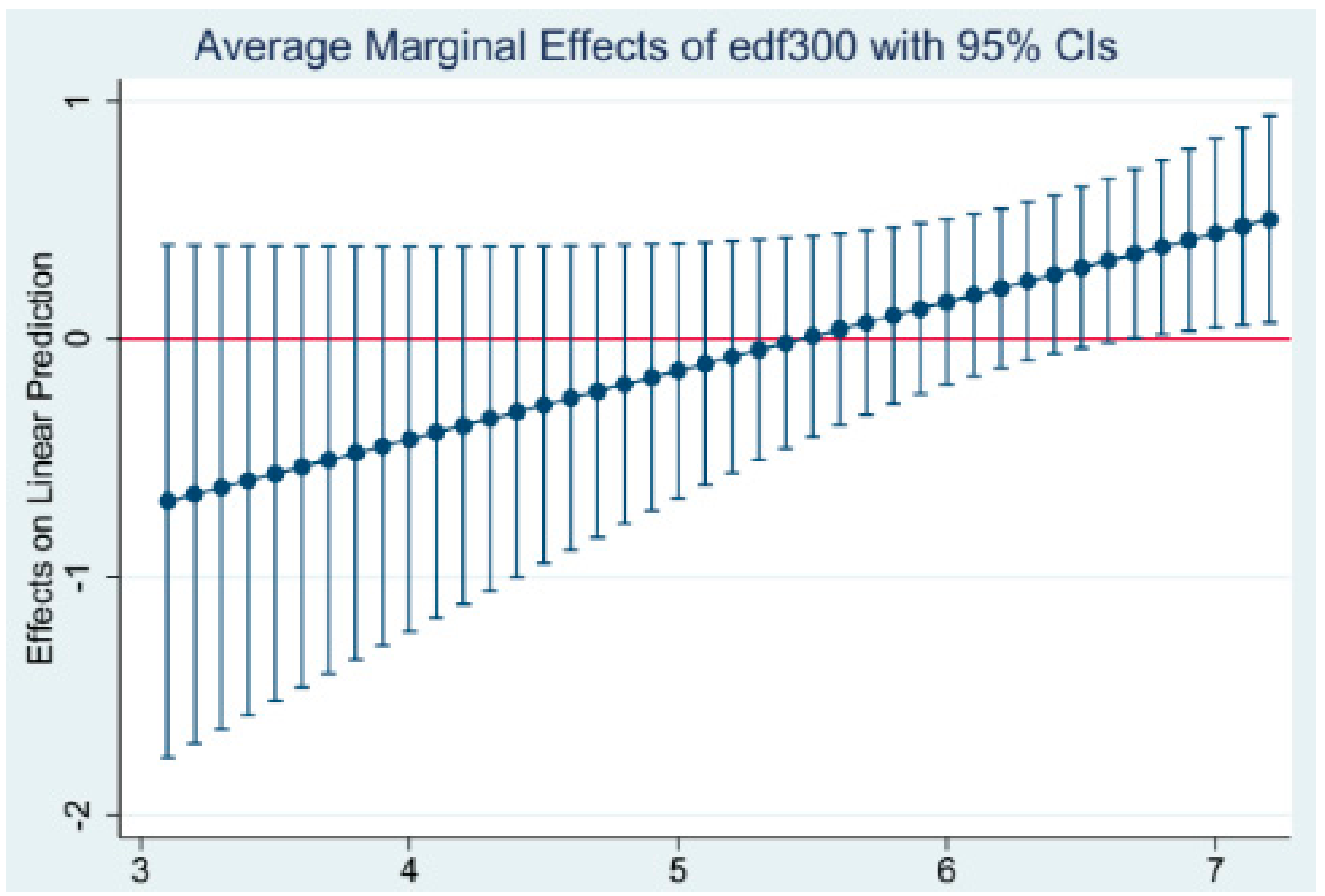

Figure 3. Moderation effect of SN in the relationship between EDE and EI.

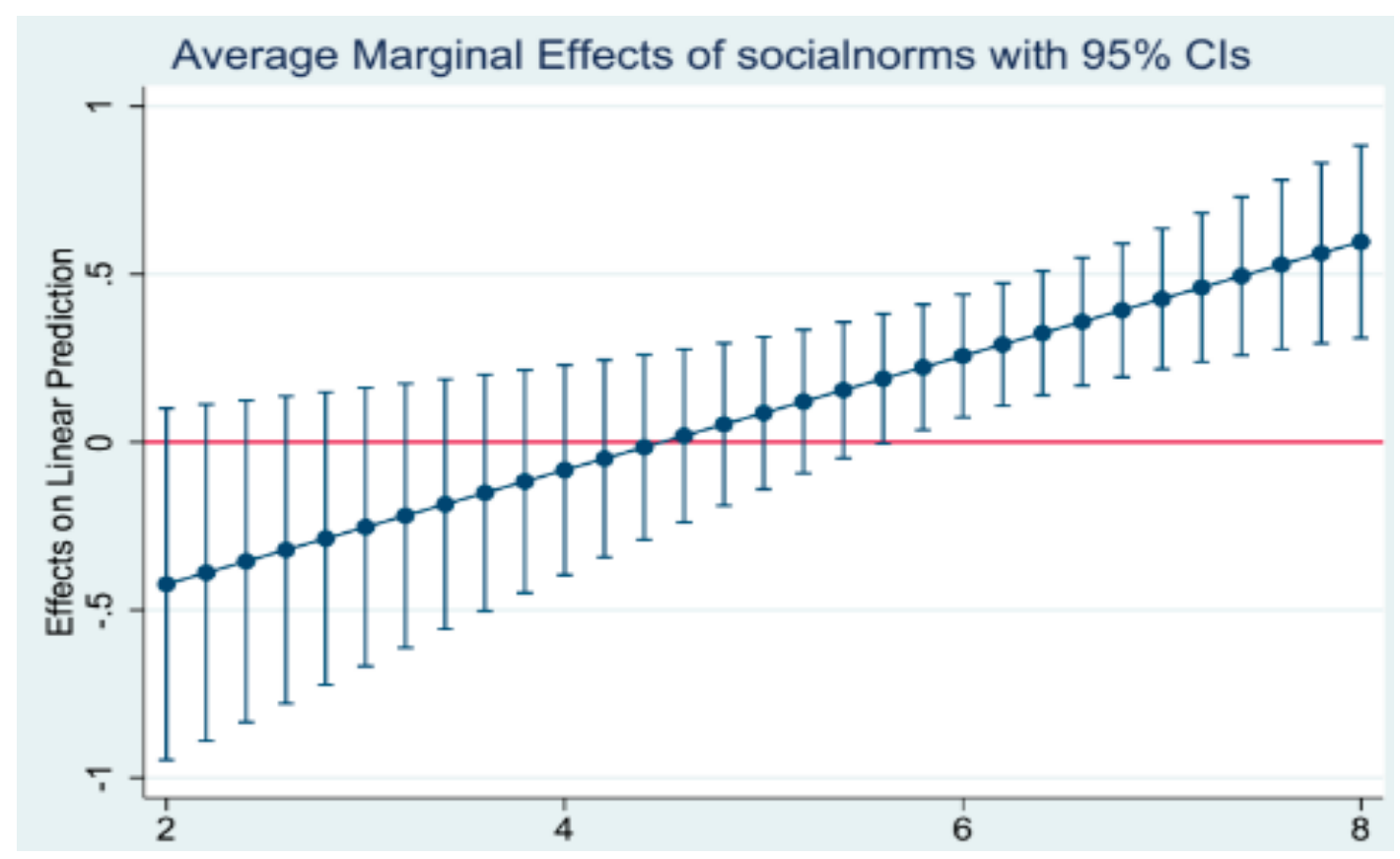

Figure 4. Effect of social norms (SN) in the relationship between entrepreneurial self-efficacy (ESE) and entrepreneurial intention (EI).

\section{Discussion and Conclusions}

Entrepreneurs are considered one of the most important agents in the dynamization of the economy. Therefore, it is necessary to understand what initiatives can improve the creation of new companies. Traditionally, the idea that entrepreneurs are "born" was the common reality. However, since the 1990s, more studies have examined the role of other factors integrated in intention models by considering aspects such as individual and contextual perceptions [10,33]. Moreover, literature 
has also examined exogenous or background factors such as the prior entrepreneurial exposure or entrepreneurial education on the likelihood of developing an entrepreneurial intention [35,54]. Despite the extent literature that examines these aspects, some contradictory results appear. For example, in the relationship between entrepreneurial education and entrepreneurial intention, we find both positive and negative effects $[16,17]$. Similarly, despite that self-efficacy has been traditionally examined as a factor that affecst entrepreneurial intention in a positive way $[6,18,20]$, others scholars find that contextual variables may alter it [7]. Lastly, social norms have also been included in intention models as they refer to those pressures or support that individuals perceive from the environment. In this regard, some studies analyze their direct effects finding contradictory results $[8,18,24,26]$, or proposing indirect effects $[19,23]$. Regarding this situation, there is a call in the literature for more comprehensively examining the relationships that could advance our understanding about a human behavior [11] such as the entrepreneurial intent.

Our study contributes to literature in several ways. First, from a theoretical point of view, we add to that research arguing that entrepreneurial education affects the entrepreneurial intention and that, then, entrepreneurs can be trained. These findings allowed us to confirm the idea that entrepreneurs can be "made" thanks to training, and that entrepreneurial education can be used as a policy instrument to increase entrepreneurial levels in a society [32]. In addition, we explain the role of social norms as a moderator of the relationship between entrepreneurial education and entrepreneurial intent and in the relationship between entrepreneurial self-efficacy and entrepreneurial intent. In this way, we sum to the line of research that calls for the examination of moderating effects [19,21,22]. We find that entrepreneurial education and self-efficacy are more likely to affect entrepreneurial intention when there is adequate social support. Specifically, this study measures the effect that a favorable environment has on entrepreneurship in a person going through entrepreneurial training. What we have found is that this effect occurs only for very high values of social norms. That is, when doing an entrepreneurship course, having friends, family, and colleagues who support the intention to undertake it is hardly decisive (except for exceptions where there is enormous support). This fact could be due to the increase in students' knowledge and the trust, resources, and inspiration that entrepreneurial programs bring to students having much greater relevance to try to undertake than the support they have from their environment. Moreover, this study measures the effect that a favorable environment has on entrepreneurship intent as a person has higher levels of self-efficacy. In this regard, we have found that for relatively high values of entrepreneurial self-efficacy, social norms do have a positive and significant impact. That is, if a person feels remarkably capable of creating a company because he/she trusts his/her skills for it, the support of his personal circle is a great help to increase the intention to undertake that person. This has important implications. It is notorious that students must be provided with resources to increase their perceived ability to create a company, and to guide them toward the culture of entrepreneurship.

Second, from an empirical point of view, we contribute to the literature thanks to the examination of a sample of engineering students. Literature analyzing the entrepreneurial intention of these kind of students is scarce and more research is needed in order to examine their particularities [28]. These students have a technical background that, together with entrepreneurial education, may allow them to recognize more business opportunities, which is line with previous research $[29,35]$. With our results, we show that it is not only important to consider the perceptions about our own personal abilities—self efficacy—or background aspects such as the education received on entrepreneurship issues. Additionally, for these kinds of students that are confident about their entrepreneurial abilities, perceiving support from their reference people would reinforce their entrepreneurial intention. This result is in line with those studies proposing that even when social norms may have a weak influence or even a non-significant effect on explaining entrepreneurial intention [18,32], it may influence (moderate) other relationships [19].

Moreover, these results have implications for policy makers, entrepreneurs, and society. On the one hand, our results show that policy makers should develop political initiatives that promote 
entrepreneurship programs, at least among those students who do not have entrepreneurial training (since our same group is made up of engineering students). Nevertheless, policy makers should take in mind the side of the coin. In many European countries, neoliberal policies on education have been implemented [55]. These ideals promote entrepreneurship as one of the pillars of education, supplanting, in turn, the traditional values of equality, participation, and social welfare. Students are divided into more and less capable, causing differences between those with entrepreneurial skills and those who lack them. Likewise, competitive and individualistic ideas are rooted in the students, instead of really preparing them for an egalitarian and shared life in society. To date, we believe that the measures taken in favor of implementing entrepreneurial education are positive as long as they are accompanied by civic values. It is dangerous not to combine policies to promote entrepreneurship with the development of skills for cooperation and social welfare. Thus, thanks to entrepreneurship, there will be economic growth in a more creative environment, and at the same time, selfish, haughty, or destructive attitudes will not be acquired. In this sense, policy makers should also promote entrepreneurial values within the society, which may encourage the social support and cooperation towards these activities. By developing these kinds of support, the positive effects of education and self-efficacy on entrepreneurial intention will be increased, which in the end, could promote the creation of employments and economic growth. On the other hand, our findings also have implications for potential entrepreneurs, who can find how entrepreneurial education can help them decide to start a business. This type of educational programs, especially for those who do not have business training such as engineering students, can help them find the resources, techniques, and ideas that allow them to transform an idea or a project into a company. Lastly, these results can have an immediate effect on society because fostering engineers' entrepreneurial intentions may generate more high-growth technology ventures to be created in future [8].

In general, this study is not without limitations that could be explored in future research. In this sense, future studies could attempt to specify what type of entrepreneurial education the students surveyed have had. Further, it would be interesting to submit two surveys to those who pass through a course, one before starting it and another at the end. Likewise, future research could go beyond the impact of entrepreneurial education in the short term (as in the entrepreneurial intention), and examine longer-term indicators, such as the foundation of a company and even business performance [37].

Author Contributions: G.A., V.H. and J.P.M. designed the study, developed the questionnaire, supervised data collection and wrote the manuscript. G.A. and V.H. analyzed the data and approved all stages of the study. All authors read, reviewed, and approved the final manuscript before submission.

Funding: This study has been partially supported by financial aid from the Spanish Ministry of Economy and Competitiveness (Grant\# ECO2015-67296-R, MINECO/FEDER) and from the Community of Madrid and European Social Fund (Grant\# CM S2015/HUM-3417-INNCOMCON). The APC was founded by University Carlos III of Madrid.

Conflicts of Interest: The authors declare no conflict of interest.

\section{Appendix A}

\section{Questionnaire}

\section{Demographic data}

1. Age:
ㄴ 18 to 20
20 to 22
22 to 25
․ More than 25 años

2. Gender:

$\square \quad$ Man 
$\square$ Woman

3. Which university career are you studying?

4. What is the approximate total monthly income of your household? (including all the family members) (INCOME):
$\square \quad \mathrm{Up}$ to $500 €$
$500 €-1000 €$
ㅁ $1000 €-2000 €$
ㅁ $2000 €-4000 €$
ㅁ $4000 €-7000 €$
ㅁ $7000 €-10,000 €$
․ More than $10,000 €$

5. Do you have any work experience? (WORKEXP):
$\square \quad$ Yes
$\square \quad$ No

6. Have you ever been self-employed? (independent worker and/or employer) (SELFEMPLOYED):
$\square \quad$ Yes
$\square \quad$ No

7. Are you planning to participate (as a worker or employer) into a company belonging to a relative of yours? (FAMIBUSSINESS):
$\square \quad$ Yes
$\square \quad$ No

\section{Entrepreneurial self-efficacy (ESE)}

I consider myself a person characterized by my...

\begin{tabular}{llllllll}
\hline & $\mathbf{1}$ & $\mathbf{2}$ & $\mathbf{3}$ & $\mathbf{4}$ & $\mathbf{5}$ & $\mathbf{6}$ & $\mathbf{7}$ \\
\hline Creativity: & $\square$ & $\square$ & $\square$ & $\square$ & $\square$ & $\square$ & $\square$ \\
Problem solving skills: & $\square$ & $\square$ & $\square$ & $\square$ & $\square$ & $\square$ & $\square$ \\
Leadership: & $\square$ & $\square$ & $\square$ & $\square$ & $\square$ & $\square$ & $\square$ \\
Comunicación skills: & $\square$ & $\square$ & $\square$ & $\square$ & $\square$ & $\square$ & $\square$ \\
Networking skills (making professional contacts): & $\square$ & $\square$ & $\square$ & $\square$ & $\square$ & $\square$ & $\square$ \\
\hline
\end{tabular}

\section{Entrepreneurial education (EDE)}

Have you ever taken a course related to entrepreneurship?

$\square \quad$ Yes

\begin{tabular}{llllllll}
\hline & 1 & 2 & 3 & 4 & 5 & 6 & 7 \\
\hline Knowledge about entrepreneurship: & $\square$ & $\square$ & $\square$ & $\square$ & $\square$ & $\square$ & $\square$ \\
Better perception of entrepreneurs: & $\square$ & $\square$ & $\square$ & $\square$ & $\square$ & $\square$ & $\square$ \\
Skills needed to be an entrepreneur: & $\square$ & $\square$ & $\square$ & $\square$ & $\square$ & $\square$ & $\square$ \\
\hline
\end{tabular}

To what extent has the course helped you to improve or develop the following aspects? *

* Only if you have answered affirmatively the previous question. 


\section{Perceived Barriers (PERCBARR)}

$\square \quad$ Rate how much you agree with the following statements

\begin{tabular}{llllllll}
\hline & $\mathbf{1}$ & $\mathbf{2}$ & $\mathbf{3}$ & $\mathbf{4}$ & $\mathbf{5}$ & $\mathbf{6}$ & $\mathbf{7}$ \\
\hline $\begin{array}{l}\text { Banks and other financial institutions do not easily give credit to startups: } \\
\text { Laws and government regulations are an obstacle to create a company: }\end{array}$ & $\square$ & $\square$ & $\square$ & $\square$ & $\square$ & $\square$ & $\square$ \\
$\begin{array}{l}\text { It is difficult to find an innovative business idea that has never been put } \\
\text { into practice: }\end{array}$ & $\square$ & $\square$ & $\square$ & $\square$ & $\square$ & $\square$ & $\square$ \\
& $\square$ & $\square$ & $\square$ & $\square$ & $\square$ & $\square$ & $\square$ \\
\hline
\end{tabular}

\section{Perceived support (PERCSUPP)}

$\square \quad$ Rate how much you agree with the following statements

\begin{tabular}{llllllll}
\hline & $\mathbf{1}$ & $\mathbf{2}$ & $\mathbf{3}$ & $\mathbf{4}$ & $\mathbf{5}$ & $\mathbf{6}$ & $\mathbf{7}$ \\
\hline University environment is creative and inspires to develop business ideas: & $\square$ & $\square$ & $\square$ & $\square$ & $\square$ & $\square$ & $\square$ \\
Aid such as qualified consultants and support service for new companies & & & & & & & \\
is accessible: & $\square$ & $\square$ & $\square$ & $\square$ & $\square$ & $\square$ & $\square$ \\
In Spain, society has a positive view of entrepreneurs: & $\square$ & $\square$ & $\square$ & $\square$ & $\square$ & $\square$ & $\square$ \\
\hline
\end{tabular}

\section{Reasons to be a self-employed (REASSELFEMPL)}

$\square \quad$ Rate how much you agree with the following statements

\begin{tabular}{llllllll}
\hline & $\mathbf{1}$ & $\mathbf{2}$ & $\mathbf{3}$ & $\mathbf{4}$ & $\mathbf{5}$ & $\mathbf{6}$ & $\mathbf{7}$ \\
\hline For me, stability and safety in my work is very important: & $\square$ & $\square$ & $\square$ & $\square$ & $\square$ & $\square$ & $\square$ \\
I would love to have a challenging, interesting and exciting job: & $\square$ & $\square$ & $\square$ & $\square$ & $\square$ & $\square$ & $\square$ \\
For me, it is very important to be autonomous in my work: & $\square$ & $\square$ & $\square$ & $\square$ & $\square$ & $\square$ & $\square$ \\
I really like to have authority and decision power: & $\square$ & $\square$ & $\square$ & $\square$ & $\square$ & $\square$ & $\square$ \\
\hline
\end{tabular}

\section{Social Norms (SN)}

$\square \quad$ Rate how much you agree with the following statements

\begin{tabular}{llllllll}
\hline & $\mathbf{1}$ & $\mathbf{2}$ & $\mathbf{3}$ & $\mathbf{4}$ & $\mathbf{5}$ & $\mathbf{6}$ & $\mathbf{7}$ \\
\hline My family would agree with my decision to start a business on my own: & $\square$ & $\square$ & $\square$ & $\square$ & $\square$ & $\square$ & $\square$ \\
My friends would agree with my decision to start a business on my own: & $\square$ & $\square$ & $\square$ & $\square$ & $\square$ & $\square$ & $\square$ \\
My colleagues would agree with my decision to start a business on my own: & $\square$ & $\square$ & $\square$ & $\square$ & $\square$ & $\square$ & $\square$ \\
I care about and I am influenced by the opinion of my circle of close people: & $\square$ & $\square$ & $\square$ & $\square$ & $\square$ & $\square$ & $\square$ \\
\hline
\end{tabular}

\section{Entrepreneurial intention (EI)}

$\square \quad$ Rate how much you agree with the following statements

\begin{tabular}{llllllll}
\hline & $\mathbf{1}$ & $\mathbf{2}$ & $\mathbf{3}$ & $\mathbf{4}$ & $\mathbf{5}$ & $\mathbf{6}$ & $\mathbf{7}$ \\
\hline I have the firm intention to start a business at some point: & $\square$ & $\square$ & $\square$ & $\square$ & $\square$ & $\square$ & $\square$ \\
There is high probability I will start a business within the next 5 years: & $\square$ & $\square$ & $\square$ & $\square$ & $\square$ & $\square$ & $\square$ \\
I have a great disposition to put effort to start my own company: & $\square$ & $\square$ & $\square$ & $\square$ & $\square$ & $\square$ & $\square$ \\
\hline
\end{tabular}




\section{Appendix B}

Descriptive statistics of the questionnaire's variables

\begin{tabular}{|c|c|c|c|c|c|}
\hline Variable & Obs. & Mean & S.D. & Min & $\operatorname{Max}$ \\
\hline AGE & 208 & 1.913462 & 0.599687 & 1 & 4 \\
\hline GENDER & 208 & 1.677885 & 0.468414 & 1 & 2 \\
\hline INCOME & 208 & 2.322115 & 1.04816 & 1 & 5 \\
\hline WORKEXP & 208 & 0.528846 & 0.500372 & 0 & 1 \\
\hline SELFEMPL & 208 & 0.139423 & 0.347223 & 0 & 1 \\
\hline FAMIBUS & 208 & 0.129808 & 0.336903 & 0 & 1 \\
\hline Creativity & 208 & 4.807692 & 1.204476 & 2 & 7 \\
\hline Problem Resolution & 208 & 5.716346 & 0.863272 & 2 & 7 \\
\hline Leadership & 208 & 5.240385 & 1.266401 & 1 & 7 \\
\hline Communication abilities & 208 & 4.903846 & 1.329845 & 1 & 7 \\
\hline Networking & 208 & 4.394231 & 1.454085 & 1 & 7 \\
\hline Banks & 208 & 4.6875 & 1.263932 & 1 & 7 \\
\hline Laws & 208 & 4.802885 & 1.43274 & 1 & 7 \\
\hline Ideas & 208 & 4.807692 & 1.563947 & 1 & 7 \\
\hline University Environment & 208 & 3.879808 & 1.60614 & 1 & 7 \\
\hline Access to grants & 208 & 3.841346 & 1.150015 & 1 & 6 \\
\hline Entrepreneur image & 208 & 3.836538 & 1.651295 & 1 & 7 \\
\hline Security & 208 & 5.653846 & 1.225882 & 1 & 7 \\
\hline Interesting & 208 & 6.216346 & 0.981137 & 1 & 7 \\
\hline Autonomy & 208 & 5.600962 & 1.089874 & 2 & 7 \\
\hline Authority & 208 & 5.360577 & 1.207778 & 1 & 7 \\
\hline Family & 208 & 5.052885 & 1.484897 & 1 & 7 \\
\hline Friends & 208 & 5.596154 & 1.212011 & 2 & 7 \\
\hline Fellows & 208 & 5.384615 & 1.186133 & 1 & 7 \\
\hline Closest friends & 208 & 4.903846 & 1.554294 & 1 & 7 \\
\hline Sometime & 208 & 3.745192 & 1.713114 & 1 & 7 \\
\hline In 5 years & 208 & 2.653846 & 1.574367 & 1 & 7 \\
\hline Effort & 208 & 3.822115 & 1.949134 & 1 & 7 \\
\hline
\end{tabular}

\section{References}

1. Crijns, H.; Vermeulen, S. Survey: How Entrepreneurial Are Our Flemish Students? Flanders District of creativity: Leuven, Belgium, 2007.

2. Karimi, S.; Biemans, H.J.A.; Lans, T.; Chizari, M.; Mulder, M. The Impact of Entrepreneurship Education: A Study of Iranian Students' Entrepreneurial Intentions and Opportunity Identification. J. Small Bus. Manag. 2016, 54, 187-209. [CrossRef]

3. Turker, D.; Sonmez Selcuk, S. Which factors affect entrepreneurial intention of university students? J. Eur. Ind. Train. 2009, 33, 142-159. [CrossRef]

4. European Commission. Entrepreneurship 2020 Action Plan: Communication from the Commission to the European Parliament, the Council, the European Economic and the Committee of the Regions; European Commission: Brussels, Belgium, 2013.

5. Fietze, S.; Boyd, B. Entrepreneurial intention of Danish students: A correspondence analysis. Int. J. Entrep. Behav. Res. 2017, 23, 656-672. [CrossRef]

6. Saeed, S.; Yousafzai, S.Y.; Yani-De-Soriano, M.; Muffatto, M. The role of perceived university support in the formation of students' entrepreneurial intention. J. Small Bus. Manag. 2015, 53, 1127-1145. [CrossRef]

7. Piperopoulos, P.; Dimov, D. Burst Bubbles or Build Steam? Entrepreneurship Education, Entrepreneurial Self-Efficacy, and Entrepreneurial Intentions. J. Small Bus. Manag. 2015, 53, 970-985. [CrossRef] 
8. Souitaris, V.; Zerbinati, S.; Al-Laham, A. Do entrepreneurship programmes raise entrepreneurial intention of science and engineering students? The effect of learning, inspiration and resources. J. Bus. Ventur. 2007, 22, 566-591. [CrossRef]

9. Thompson, E.R. Individual Entrepreneurial Intent: Construct Clarification and Development of an Internationally Reliable Metric. Entrep. Theory Pract. 2009, 33, 669-694. [CrossRef]

10. Ajzen, I. The theory of planned behavior. Organ. Behav. Hum. Decis. Process. 1991, 50, 179-211. [CrossRef]

11. Ajzen, I. The theory of planned behaviour: Reactions and reflections. Psychol. Health 2011, 26, 1113-1127. [CrossRef]

12. Fayolle, A.; Gailly, B. The Impact of Entrepreneurship Education on Entrepreneurial Attitudes and Intention: Hysteresis and Persistence. J. Small Bus. Manag. 2015, 53, 75-93. [CrossRef]

13. Matlay, H. Entrepreneurship education in UK business schools. J. Small Bus. Enterp. Dev. 2005, 12, 627-643. [CrossRef]

14. Karimi, S.; Biemans, H.J.A.; Lans, T.; Aazami, M.; Mulder, M. Fostering students' competence in identifying business opportunities in entrepreneurship education. Innov. Educ. Teach. Int. 2016, 53, 215-229. [CrossRef]

15. Braidot, N.; Cesar, R.; González, V. Competencias emprendedoras en la formación de ingenieros, un desafío necesario. In Proceedings of the II Congreso Argentino de Ingeniería (CADI 2014), Tucumán, Argentina, 17-19 September 2014.

16. Oosterbeek, H.; Praag, M.; Ijsselstein, A. The impact of entrepreneurship education on entrepreneurship skills and motivation. Eur. Econ. Rev. 2010, 54, 442-454. [CrossRef]

17. Peterman, N.E.; Kennedy, J. Enterprise Education: Influencing Students' Perceptions of Entrepreneurship. Entrep. Theory Pract. 2003, 28, 129-144. [CrossRef]

18. Thomas, A.; Passaro, R.; Scandurra, G. The Perception of the Contextual Factors as Predictor of Entrepreneurial Intent: Evidences from an Empirical Survey. J. Enterp. Cult. 2014, 22, 375-400. [CrossRef]

19. Tsai, K.; Chang, H.; Peng, C. Extending the link between entrepreneurial self-efficacy and intention: A moderated mediation model. Int. Entrep. Manag. J. 2016, 12, 445-463. [CrossRef]

20. Zhao, H.; Seibert, S.E.; Hills, G.E. The Mediating Role of Self-Efficacy in the Development of Entrepreneurial Intentions. J. Appl. Psychol. 2005, 90, 1265-1272. [CrossRef] [PubMed]

21. Hsu, D.K.; Burmeister-Lamp, K.; Simmons, S.A.; Foo, M.; Hong, M.C.; Pipes, J.D. “I know I can, but I don't fit": Perceived fit, self-efficacy, and entrepreneurial intention. J. Bus. Ventur. 2019, 34, 311. [CrossRef]

22. Schlaegel, C.; Koenig, M. Determinants of Entrepreneurial Intent: A Meta-Analytic Test and Integration of Competing Models. Entrep. Theory Pract. 2014, 38, 291-332. [CrossRef]

23. Liñán, F. Skill and value perceptions: How do they affect entrepreneurial intentions? Int. Entrep. Manag. J. 2008, 4, 257-272. [CrossRef]

24. Trivedi, R. Does University play a significant role in shaping entrepreneurial intention? A Cross-country Comparative Analysis. J. Small Bus. Enterp. Dev. 2016, 23, 790-811. [CrossRef]

25. Bae, T.J.; Qian, S.; Miao, C.; Fiet, J.O. The Relationship between Entrepreneurship Education and Entrepreneurial Intentions: A Meta-Analytic Review. Entrep. Theory Pract. 2014, 38, 217-254. [CrossRef]

26. Krueger, N.F.; Reilly, M.D.; Carsrud, A.L. Competing models of entrepreneurial intentions. J. Bus. Ventur. 2000, 15, 411-432. [CrossRef]

27. Law, K.; Breznik, K. Impacts of innovativeness and attitude on entrepreneurial intention: Among engineering and non-engineering students. Int. J. Technol. Des. Educ. 2017, 27, 683-700. [CrossRef]

28. Maresch, D.; Harms, R.; Kailer, N.; Wimmer-Wurm, B. The impact of entrepreneurship education on the entrepreneurial intention of students in science and engineering versus business studies university programs. Technol. Forecast. Soc. Chang. 2016, 104, 172-179. [CrossRef]

29. Hassan, R.; Wafa, S. Predictors towards entrepreneurial intention: A Malaysian case study. Asian J. Bus. Manag. Sci. 2012, 1, 1-10.

30. Wang, J.-H.; Chang, C.-C.; Yao, S.-N.; Liang, C. The contribution of self-efficacy to the relationship between personality traits and entrepreneurial intention. High. Educ. 2016, 72, 224. [CrossRef]

31. Camelo-Ordaz, C.; Diánez-González, J.P.; Ruiz-Navarro, J. The influence of gender on entrepreneurial intention: The mediating role of perceptual factors. Brq Bus. Res. Q. 2016, 19, 261-277. [CrossRef]

32. Liñán, F.; Rodríguez-Cohard, J.; Rueda-Cantuche, J. Factors affecting entrepreneurial intention levels: A role for education. Int. Entrep. Manag. J. 2011, 7, 195-218. [CrossRef] 
33. Shapero, A.; Sokol, L. The social dimensions of entrepreneurship. In Encyclopedia of Entrepreneurship; Prentice-Hall: Englewood Cliffs, NJ, USA, 1982; pp. 72-90.

34. Zapkau, F.B.; Schwens, C.; Steinmetz, H.; Kabst, R. Disentangling the effect of prior entrepreneurial exposure on entrepreneurial intention. J. Bus. Res. 2015, 68, 639-653. [CrossRef]

35. Zhang, Y.Y.; Duysters, G.G.; Cloodt, M.M. The role of entrepreneurship education as a predictor of university students' entrepreneurial intention. Int. Entrep. Manag. J. 2014, 10, 623-641. [CrossRef]

36. Liñán, F.; Moriano, J.A.; Jaén, I. Individualism and entrepreneurship: Does the pattern depend on the social context? Int. Small Bus. J. 2016, 34, 760-776. [CrossRef]

37. Nabi, G.; Liñán, F.; Fayolle, A.; Krueger, N.; Walmsley, A. The Impact of Entrepreneurship Education in Higher Education: A Systematic Review and Research Agenda. Acad. Manag. Learn. Educ. 2017, 16, 277-299. [CrossRef]

38. Autio, E.; Keeley, R.H.; Klofsten, M.; Parker, G.G.C.; Hay, M. Entrepreneurial Intent among Students in Scandinavia and in the USA. Enterp. Innov. Manag. Stud. 2001, 2, 145-160. [CrossRef]

39. Martin, B.C.; McNally, J.J.; Kay, M.J. Examining the formation of human capital in entrepreneurship: A meta-analysis of entrepreneurship education outcomes. J. Bus. Ventur. 2013, 28, 211-224. [CrossRef]

40. Krueger, N.F.; Brazeal, D.V. Entrepreneurial Potential and Potential Entrepreneurs. Entrep. Theory Pract. 1994, 18, 91-104. [CrossRef]

41. Athayde, R. Measuring Enterprise Potential in Young People. Entrep. Theory Pract. 2009, 33, 481-500. [CrossRef]

42. Saks, N.T.; Gaglio, C.M. Can opportunity identification be taught? J. Entrep. Cult. 2002, 10, $313-347$. [CrossRef]

43. Veciana, J.; Aponte, M.; Urbano, D. University Students' Attitudes towards Entrepreneurship: A Two Countries Comparison. Int. Entrep. Manag. J. 2005, 1, 165-182. [CrossRef]

44. Ajzen, I. Nature and operation of attitudes. Annu. Rev. Psychol. 2001, 52, 27-58. [CrossRef] [PubMed]

45. Giannetti, M.; Simonov, A. On the determinants of entrepreneurial activity: Social norms, economic environment and individual characteristics. Swed. Econ. Policy Rev. 2004, 11, 269-313. [CrossRef]

46. Schwarz, E.J.; Wdowiak, M.A.; Almer-Jarz, D.A.; Breitenecker, R.J. The effects of attitudes and perceived environment conditions on students' entrepreneurial intent. Educ. Train. 2009, 51, 272-291. [CrossRef]

47. Liñán, F.; Urbano, D.; Guerrero, M. Regional variations in entrepreneurial cognitions. Entrep. Reg. Dev. 2011, 23, 187-215. [CrossRef]

48. Liñán, F.; Santos, F. Does Social Capital Affect Entrepreneurial Intentions? Int. Adv. Econ. Res. 2007, 13, 443-453. [CrossRef]

49. Chen, C.C.; Greene, P.G.; Crick, A. Does entrepreneurial self-efficacy distinguish entrepreneurs from managers? J. Bus. Ventur. 1998, 13, 295-316. [CrossRef]

50. Bandura, A. Self-Efficacy: The Exercise of Control; Worth Publishers: New York, NY, USA, 1997.

51. Krueger, N.F.; Dickson, P.R. How believing in ourselves increases risk taking: Perceived self-efficacy and opportunity recognition. Decis. Sci. 1994, 25, 385-400. [CrossRef]

52. Lüthje, C.; Franke, N. The 'making' of an entrepreneur: Testing a model of entrepreneurial intent among engineering students at MIT. $R$ D Manag. 2003, 33, 135-147. [CrossRef]

53. Kolenikov, S.; Angeles, G. The Use of Discrete Data in PCA: Theory, Simulations and Applications to Socieconomic Indices; Routledge, Taylor \& Francis Group: London, UK; New York, NY, USA, 2004; pp. 1-59.

54. Kolvereid, L.; Moen, Ø. Entrepreneurship among business graduates: Does a major in entrepreneurship make a difference? J. Eur. Ind. Train. 1997, 21, 154-160. [CrossRef]

55. Komulainen, K.; Naskali, P.; Korhonen, M.; Keskitalo-Foley, S. Internal Entrepreneurship-A Trojan horse of the neoliberal governance of education? Finnish pre-and in-service teachers' implementation of and resistance towards entrepreneurship. J. Crit. Educ. Policy Stud. 2011, 9, 342-374.

(C) 2019 by the authors. Licensee MDPI, Basel, Switzerland. This article is an open access article distributed under the terms and conditions of the Creative Commons Attribution (CC BY) license (http://creativecommons.org/licenses/by/4.0/). 